\title{
Persistence of Several Herbicides in a Soil Cropped to Sugarcane
}

\author{
L. C. Liu, H. R. Cibes-Viade, and J. Gonzdilez-Ibdĩnez
}

\section{INTRODUCTION}

Use of soil-applied herbicides in our sugarcane plantations is increasing annually. The importance of obtaining exact information on the degree of persistence of such chemicals in local soils is obvious.

The persistence was investigated under greenhouse conditions $(5)^{2}$ of 2-chloro-4-(ethylamino)-6-(isopropylamino)-s-triazine (Atrazine), 2-(ethylamino)-4-(isopropylamino)-6-(methylthio)-s-triazine (Ametryne), 3-(3,4dichlorophenyl)-1,1-dimethylurea (Diuron) and 2,4-bis(isopropylamino)6-(methylthio)-s-triazine (Prometryne). Diuron was found to be the most persistent in most soils; Prometryne the least, with Ametryne and Atrazine intermediate in this respect. Because the results of the above-mentioned studies were obtained under controlled conditions, it seemed desirable to determine if these herbicides behaved in the same way under actual field conditions.

The present field studies on the persistence of Ametryne, Diuron, 1,1dimethyl-3-( $\alpha, \alpha, \alpha$-trifluoro-m-tolyl) urea (Fluometuron), 3-(hexahydro4,7-methanoidan-5-yl)-1,1-dimethyl urea (Norea), Prometryne, and 3-tert-butyl-5-chloro-6-methyl uracil (Terbacil) in a Mabi clay soil were thus conducted to determine the validity of our previous findings with respect to their residual activity.

\section{MATERIALS AND METHODS}

The experiment was initiated in 1967 at the Gurabo Substation for the purpose of evaluating the efficiency of various herbicides on the control of weeds in fields planted to two sugarcane varieties, namely, P.R. 980 and P.R. 1048. It also was intended to determine the effects of these herbicides on yield of cane, sugar percent cane and yield of sugar per acre.

The experiment was established on a fertile and productive Mabi clay soil derived from material in part residual and in part colluvial and alluvial. Mabí clay is characterized by a grayish-brown neutral plastic heavy clay surface soil and yellowish-brown plastic sticky neutral subsoil. The average organic matter content, cation exchange capacity, clay content and $\mathrm{pH}$ for

1 Assistant Phytophysiologist, Phytophysiologist and Assistant Biologist, respectively, Agricultural Experiment Station, Mayagüez Campus, University of Puerto Rico, Río Piedras, P.R.

Italic numbers in parentheses refer to Literature Cited, p. 152. 
this soil are 4.5 percent, 43.1 meq. per 100 g. soil, 44.9 percent and 6.3, respectively.

Ametryne, Diuron, Fluometuron, Prometryne and Norea were applied at rates of $1,2,4,8,16$, and 32 pounds per acre. Terbacil, on the other hand, was applied at the somewhat lower rates of $2,4,8$, and 16 pounds per acre. The experimental plots were laid out in a randomized complete block design with six replications per treatment. The cane in the various

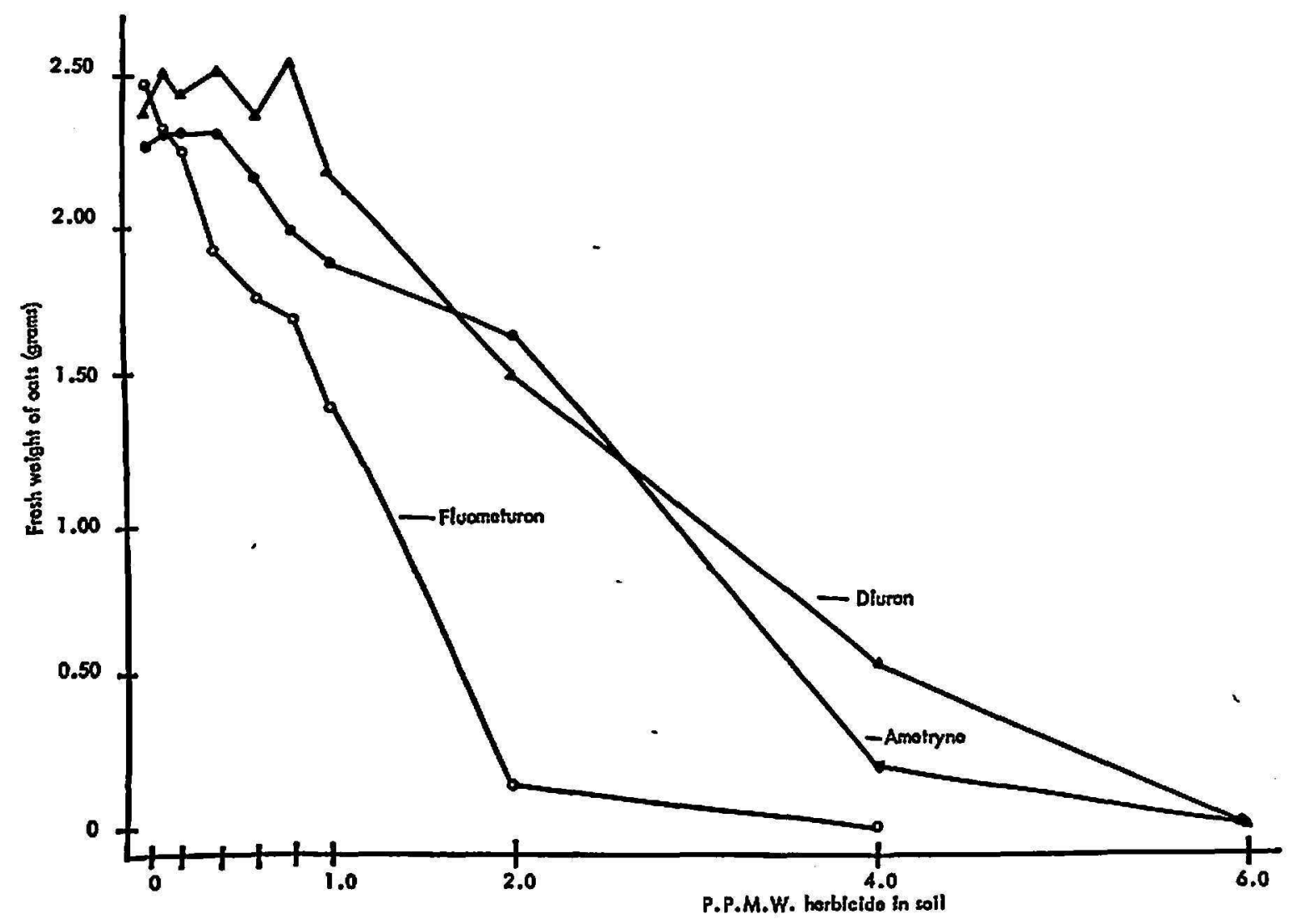

Fic. 1. - Standard curves of Ametryne, Diuron and Fluometuron constructed by plotting the fresh weight of osts against P.P.M.W. herbicide in soil.

experimental plots was harvested by the end of a 12-month growth period. A bioassay study was conducted after the harvesting operation was completed to determine the presence and relative amounts of the herbicides still active in the soil profile. To attain this purpose, soil core samples were taken at different depths ( 0 to 4 inches, 4 to 8 inches, 8 to 12 inches) from plots comprised in one of the experimental blocks. The collected soil samples were air-dried individually and stored for immediate bioassay. Soil samples to be bioassayed were either kept unmixed or diluted with untreated soil to lower the herbicide concentration to a level or range at which oats (Avena sativa $\mathrm{L}$.) could be used accurately for quantitative herbicide 
determination. The dilution ratios between the treated and untreated soil were: 1:0 (no dilution), 1:1, 1:2, 1:4, 1:8, and 1:16. Five-ounce aluminum foil containers were filled with $120 \mathrm{~g}$. of either the diluted or undiluted soil samples for assay of the various concentrations of the herbicides. The bioassay procedure adopted was that employed previously (3).

This procedure also was used for the construction of standard curves. Series of known concentrations (from 0.1 to 6 p.p.m.) of the six herbicides

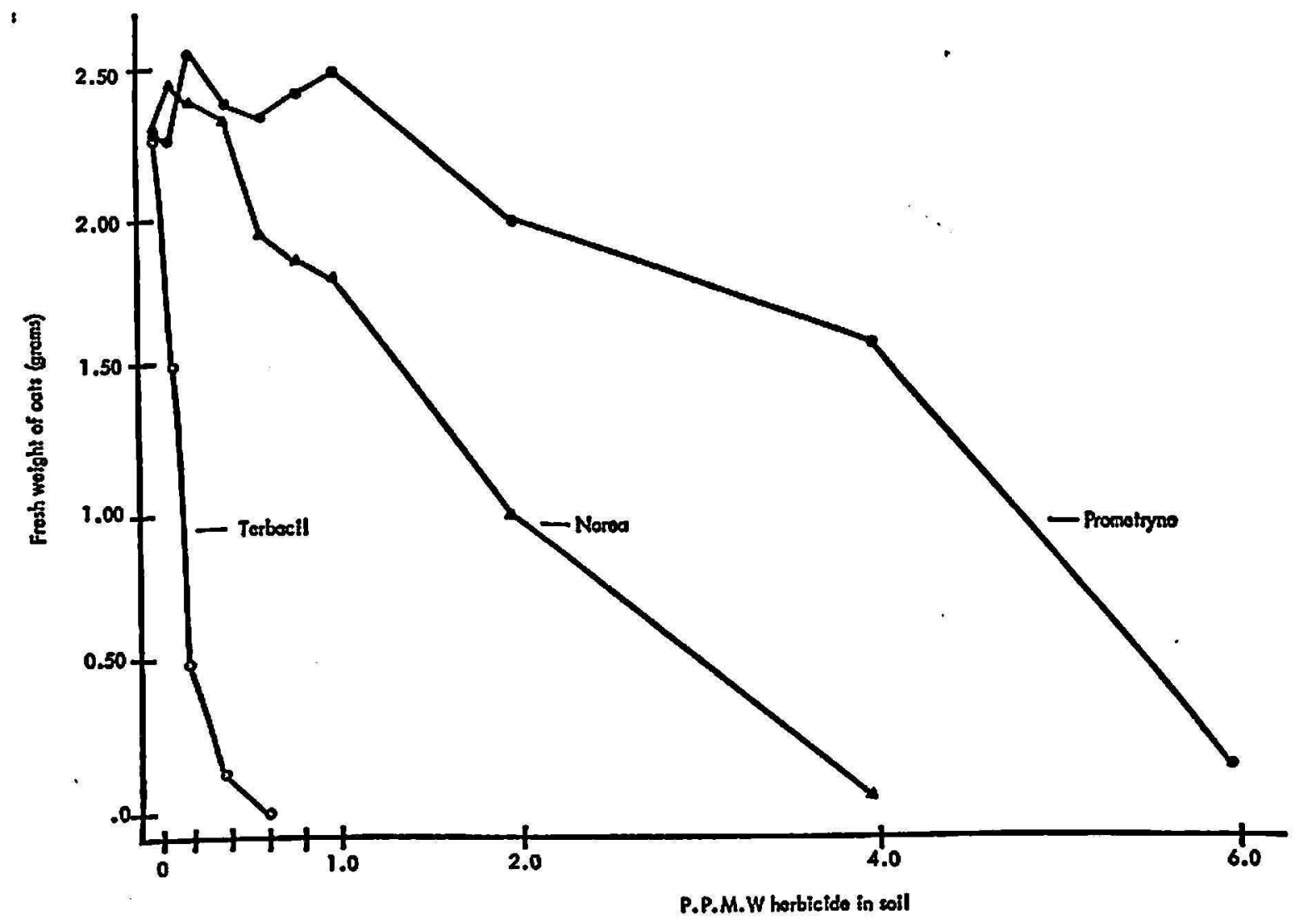

Fia. 2. Standard curves of Norea, Prometryne and Terbacil constructed by plotting the fresh weight of oats against P.P.M.W. herbicide in soil.

were prepared in triplicate by applying the predetermined amount of stock solutions of each one to untreated Mabi clay. Six standard curves thus were constructed by plotting the fresh weight of harvested oat plants against the concentration of the various herbicides (figs. 1 and 2). The quantities of each herbicide remaining in the treated soil samples were determined following the method described by Dawson et al. (2). This involves fitting the fresh weights of oats grown in treated soil to the corresponding standard curves. Where soil samples of different dilution series were used, the concentrations obtained from standard curves were multiplied by their respective dilution factors. 


\section{RESULTS}

Table 1 shows the bioassayed concentration of Ametryne, Diuron, Fluometuron, Norea, Prometryne and Terbacil present in the soil samples collected from experimental plots at three different depths 13 months following the differential treatment. The amount of herbicide residue present in the

TABLE 1.-Herbicide concentration (part per million by weight) of Amelryne, Diuron, Fluomeluron, Herban, Promelryne and Terbacil in a Mabi clay at different depths, 18 months after trealment'

\begin{tabular}{lcccc}
\hline \multirow{2}{*}{ Herbicide } & Rate applied & \multicolumn{3}{c}{ Soil depth-inches } \\
\cline { 3 - 5 } & & $0-4$ & $4-8$ & $8-12$ \\
\hline \multirow{3}{*}{ Ametryne } & Pounds per acre & $P . p . m . w$. & $P . p . m . w$. & $P . p . m . w$. \\
& 4 & 0.88 & 0.00 & 0.00 \\
Diuron & 8 & .81 & .00 & .00 \\
& 16 & .73 & .41 & .00 \\
& 32 & 2.36 & .91 & .00 \\
Fluometuron & 4 & 1.32 & 1.48 & .00 \\
& 8 & 1.33 & .42 & 1.28 \\
& 16 & 3.05 & 1.25 & 1.17 \\
Norea & 32 & 3.51 & 1.51 & 1.30 \\
& 4 & 1.51 & .85 & .56 \\
& 8 & 2.52 & .60 & .30 \\
& 16 & 3.30 & .81 & 1.35 \\
& 32 & 3.19 & 1.71 & 1.08 \\
& 4 & .00 & .63 & .42 \\
& 8 & .50 & 1.56 & 1.90 \\
& 16 & .00 & 1.49 & 1.54 \\
& 32 & .84 & .89 & 2.85 \\
& 4 & .19 & .00 & .00 \\
& 8 & .63 & .56 & .00 \\
& 16 & 1.25 & .15 & .00 \\
& 32 & 1.57 & .67 & .00 \\
& 2 & .01 & .06 & .01 \\
& 4 & .04 & .20 & .05 \\
& 16 & .04 & .22 & .04 \\
& .10 & .39 & .12 \\
\hline & & & &
\end{tabular}

1 Each figure is the mean of three replications.

soil at the 0- to 4-inch depth was found to be relatively low in plots treated with 4 pounds per acre of Ametryne, Diuron, Fluometuron, Norea or Prometryne, or 2 pounds per acre of Terbacil. The residual concentration of these chemicals seemed to increase in this soil layer as the rate of application was increased. Thus, Fluometuron and Diuron were detected at rather high concentrations when applied at rates of 16 or 32 pounds per acre. At the two respective higher rates, only small to moderate amounts of Ame- 
tryne, Norea, Prometryne or Terbacil were present. Data shown in table 1 also indicates that Fluometuron, Diuron, Ametryne and Prometryne did not penetrate beyond the 0 - to 4 -inch depth in appreciable amounts, regardless of the concentration. This was not the case, however, with Terbacil and Norea. The greatest amounts of these were found to accumulate in the 4- to 8-inch and 8- to 12-inch depths, respectively. Apparently, the greater mobility of Terbacil and Norea may account for this. Absence of Ametryne and Prometryne from the 8- to 12-inch soil layer, on the other hand, further confirms our previous findings on the low penetrativity of these triazine herbicides ( $(3)$.

The data presented in table 1 demonstrates further that Diuron persisted in the soil in higher amounts than Ametryne or Prometryne, while Ametryne was slightly more persistent than Prometryne. These results also are in close agreement with those obtained previously. No previous persistence studies have been conducted in Puerto Rico with the newly-introduced herbicides Fluometuron, Norea and Terbacil.

The results obtained in the field experiments conducted by Cibes and González-Ibáñez (1) indicate that tolerance of sugarcane is rather narrow to phenyl urea herbicides such as Fluometuron and Diuron when compared with tolerance toward s-triazine herbicides. Precautions should be taken, therefore, when using these herbicides at rates exceeding 4 pounds per acre. Conversely, slightly higher rates of Ametryne and and Prometryne can be applied to sugarcane without harmful effect. This is due to the existence of a self-detoxifying mechanism in sugarcane which converts triazine herbicides into hydroxy analogs. Problems to sugarcane caused by the immediate carry-over of herbicides are not encountered frequently in Puerto Rico. This is because a rotation schedule is practically non-existent on the plantations. Dangerous accumulations of potentially-hazardous weedkilling chemicals can result from repeated or excessive use.

\section{SUMMARY}

Experimental plots were treated with Ametryne, Diuron, Fluometuron, Norea and Prometryne at the rates of 4, 8, 16 and 32 pounds per acre. Terbacil was applied at the rates of $2,4,8$ and 16 pounds per acre 13 months prior to soil sampling. Herbicide residues in soil samples collected from experimental plots were bioassayed using oats (Avena sativa $\mathbf{L}$.) as the indicator plant. Residues present in the soil at the 0 - to 4 -inch depth were found to be relatively low in plots treated with 4 pounds per acre of Ametryne, Diuron, Fluometuron, Norea or Prometryne, or 2 pounds per acre of Terbacil. Residues were found to increase in the 0- to 4-inch depth as the rate of herbicide was increased. Fluometuron and Diuron were detected at rather high concentrations when applied at 16 and 32 pounds per acre. At 
the corresponding higher rates, only small to moderate amounts of Ametryne, Norea, Prometryne and Terbacil were detected. In general, Fluometuron, Diuron, Ametryne and Prometryne did not penetrate in appreciable amounts beyond the 0 - to 4 -inch depth regardless of the concentration. However, the greatest amount of Terbacil and Norea were found to accumulate in the 4- to 8-inch and 8- to 12-inch depths, respectively.

\section{RESUMEN}

Los yerbicidas Ametryne, Diuron, Fluometuron, Norea y Prometryne fueron aplicados a parcelas experimentales, a razón de 4, 8, 16 y 32 libras por acre. En cambio, el Terbacil se aplicó en cantidades de 2, 4, 8 y 16 libras, 13 meses antes de que se tomaran muestras de suelo de las referidas parcelas. El contenido de residuos yerbicidas en dichas muestras fue determinado mediante un ensayo biológico utilizándose, con tal propósito, la variedad de avena "Kanota" (Avena sativa $\mathrm{L}$.) como planta indicadora. Se encontró que la presencia de residuos fue relativamente baja a una profundidad de 0 a 4 pulgadas en las parcelas tratadas con 4 libras de Ametryne, Diuron, Fluometuron, Norea y Prometryne o con 2 libras de Terbacil, por acre. Se hallo, además, que a dicha profundidad la cantidad de residuos en el suelo aumentó en proporción a las dosis aplicadas. Por otro lado se detectaron altas concentraciones de Fluometuron y de Diuron, cuando éstos se aplicaron a razón de 16 y 32 libras por acre. Sin embargo, al aplicarse idénticas dosis de Ametryne, Norea, Prometryne y Terbacil, sólo se detectaron moderadas cantidades de residuos. En términos generales, los yerbicidas Fluometuron, Diuron, Ametryne y Prometryne no penetraron en cantidades apreciables más allá del límite de 4 pulgadas, sin importar la concentración a que fueron aplicados. De otra parte, los resultados obtenidos prueban que en los casos del Terbacil y la Norea la mayor acumulación residual se encontró a las profundidades de 4 a 8 pulgadas y 8 a 12 pulgadas, respectivamente.

\section{LITERATURE CITED}

1. Cibes-Viadé, H. R. and González-Ibañez, J., unpublished data.

2. Dawson, J. H., Burns, V. F., and Clore, W. J., Residual Monuron, Diuron, and Simazine in a vineyard soil, $J$, of Weed Sci. of Amer. $16: 63-65,1968$.

3. Liu, L. C. and Cibes-Viadé, H., Influence of soil properties on the phytotoxicity of Atrazine, Ametryne, Prometryne and Diuron in Puerto Rican soils, J. Agr. Univ. P.R. 68 (4): 260-80, 1968.

4. Liu, L. C. and Cibes-Viadé, H., Leaching of Atrazine, Ametryne, and Prometryne in the soil, J. Agr. Univ. P.R. 54 (1): 5-18, 1970.

5. Liu, L. C., Cibes-Viadé, H. and González-Ibáñez, J., The persistence of Atrazine, Ametryne, Prometryne and Diuron in soils under greenhouse conditions, J. Agr. Univ. P.R. 64 (4): 631-9, 1970. 